\title{
JEZIČKA ANKSIOZNOST I ANKSIOZNOST PRI KOMUNIKACIJI NA STRANOM JEZIKU U RAZREDNOJ SITUACIJI
}

\begin{abstract}
APSTRAKT
Jezička anksioznost je faktor koji je u velikoj meri prisutan pri svakom obliku učenja stranog jezika. Jedna od osnovnih komponenti jezičke anksioznosti u razrednoj situaciji je i anksioznost pri komunikaciji, problem koji se često javlja pri usmenoj produkciji jezika. Prema tome, ovaj rad se bavi istraživanjem problema opšte jezičke anksioznosti i anksioznosti pri komunikaciji u razrednoj situaciji među učenicima šestog razreda osnovne škole. Podaci prikupljeni pomoću upitnika skalera koji predstavlja prilagođenu verziju Skale za merenje jezičke anksioznosti u razrednoj situaciji, deskriptivno se analiziraju, a potom se ispituje uticaj dodatne izloženosti nastavi engleskog jezika na ove dve vrste anksioznosti. Dobijeni podaci govore $\mathrm{u}$ prilog tome da je nedovoljan broj časova engleskog jezika u okviru redovne nastave jedan od uzroka pojave opšte jezičke anksioznosti i anksioznosti pri komunikaciji među učenicima šestog razreda osnovne škole.
\end{abstract}

Ključne reči: jezička anksioznost, anksioznost pri komunikaciji, osnovna škola, engleski jezik.

\section{FOREIGN LANGUAGEE ANXIETY AND COMMUNICATION APPREHENSION IN A CLASSROOM SITUATION}

\begin{abstract}
Foreign language anxiety is a factor that can be found in any form of learning a foreign language. One of the main components of foreign language anxiety in a classroom situation is communication apprehension, a problem faced by everyone who needs to verbally produce a foreign language. Therefore, this paper analyzes the problems of foreign language anxiety and communication apprehension of the sixth grade students of
\end{abstract}


elementary school. Data collected by questionnaire, a customized version of FLCAS - Foreign Language Classroom Anxiety Scale, are statistically analyzed in order to determine the levels of foreign language anxiety and communication apprehension among aforementioned students. In addition, the influence of attending additional classes of the English language was also analyzed, in order to determine if a more frequent exposure to foreign language influences the level of both types of language anxiety. The results showed that an insufficient exposure to the English language within a classroom, in the context of regular classes, is one of the causes of the foreign language anxiety and communication apprehension among sixth grade students of elementary school.

Key words: foreign language anxiety, communication apprehension, English, primary school.

\section{UVOD}

Veza između komunikativne kompetencije i učenja stranog jezika je sa teorijskog stanovišta veoma interesantna stručnjacima koji se bave usmenom komunikacijom i učenjem i usvajanjem stranog jezika. Jasno je da će jezička anksioznost i anksioznost pri komunikaciji imati neke zajedničke karakteristike, ali je bitno da se naglasi da se ova dva pojma ne odnose na istu pojavu. U skladu sa tim, Mihaljević Djigunović ističe da se osobe koje pate od jezičke anksioznosti istovremeno muče i s učenjem jezika i njegovom upotrebom, dok osobe koje pate od anksioznosti pri komunikaciji moraju da se uhvate u koštac samo sa jezičkom upotrebom. Kod tih osoba se retko razvija recepcijska anksioznost, a ta vrsta anksioznosti je česta kod učenika stranog jezika. Jezička anksioznost uopšte, povezana je i s određenim rizikom po ličnost osobe jer je korisnik stranog jezika svestan da svoju ličnost ne može u potpunosti da izrazi na stranom jeziku, što uglavnom nije slučaj kod osoba koje imaju problem s anksioznošću pri komunikaciji (Mihaljević Djigunović 2002: 46).

Jezička anksioznost se stoga može opisati kao jedna od najvažnijih emocija koja utiče na proces učenja stranog jezika. Ona na određen način predstavlja reakciju na ono što neki učenici doživljavaju kao pretnju svom osećaju sigurnosti ili svom samopouzdanju. Prema tome, učenje stranog jezika neretko predstavlja traumatično iskustvo za mnoge učenike, a broj učenika koji priznaju da osećaju neku vrstu anksioznosti pri izražavanju na stranom jeziku svakodnevno se povećava. S druge strane, anksioznost pri komunikaciji može da se definiše kao vrsta stidljivosti koju karakteriše anksioznost pri komunikaciji sa 
ljudima. Takva anksioznost se oseća pri usmenoj komunikaciji sa jednom ili više osoba, uglavnom pri javnom izlaganju ili pri javnom primanju informacije. Stoga je logična pretpostavka da će osoba koja ima poteškoće u komunikaciji imati isti, ako ne i veći problem, na časovima stranog jezika (Mihaljević Djigunović 2002: 20).

Prema tome, ove dve vrste anksioznosti su različite, ali opet uzajamno povezane, te ne čudi činjenica da je anksioznost pri komunikaciji jedna od 3 osnovne komponente opšte jezičke anksioznosti (Horwitz, Horwitz and Cope 1986). Pomenuta dva pojma su u neku ruku i neodvojiva jer osobe koje osećaju anksioznost pri komunikaciji jednako kao i osobe koje osećaju jezičku anksioznost uopšte imaju nisko mišljenje o sebi i svojim vrednostima, slabiji su u komunikaciji u odnosu na vršnjake, te neprestano očekuju neuspeh (Mihaljević Djigunović 2002). Osobe koje pate od jezičke anksioznosti, uz sve gore navedene probleme, imaju i osećaj da su nekompetentne za komunikaciju na stranom jeziku, kako na nivou recepcije tako i na nivou produkcije (Foss and Reitzel 1991: 131).

S obzirom na sve prethodno navedeno cilj ovog rada je da ustanovi nivo jezičke anksioznosti i anksioznosti pri komunikaciji među učenicima šestog razreda osnovne škole $(\mathrm{N}=142)$, u okviru sledećih istraživačkih zadataka:

1. Utvrditi da li je jezička anksioznost prisutna kod učenika šestog razreda osnovne škole.

2. Utvrditi da li je anksioznost pri komunikaciji prisutna kod učenika šestog razreda osnovne škole.

3. Utvrditi da li eksterni faktor koji se odnosi na pohađanje privatnih časova engleskog jezika utiče na pojavu jezičke anksioznosti $u$ razrednoj situaciji i anksioznosti pri komunikaciji.

\section{TEORIJSKI OKVIR}

Horvic, Horvic i Koup (Horwitz et al. 1986) su definisali pojam jezičke anksioznosti (engl. foreign language anxiety), ističući da je to vrsta anksioznosti vezana za specifičnu situaciju, pri čemu naglašavaju da ona u velikoj meri zavisi od drugih tipova anksioznosti. Oni su proučavanjima na ovu temu doprineli i formiranjem Skale za merenje jezičke anksioznosti u razrednoj situaciji FLCAS (engl. Foreign Language Classroom Anxiety Scale), kojom se meri nivo anksioznosti specifične za učenje stranog jezika, a zahvaljujući visokom kvalitetu i pouzdanosti ovaj instrument se koristio u mnogim istraživanjima (Aida 1994; 
Rodriguez and Abreu 2003; Goshi 2005; Pérez-Paredes and Martínez-Sánchez 2000; Horwitz et al. 1986).

Neretko se $\mathrm{u}$ istraživanjima jezičke anksioznosti nailazi na mišljenje da je ona rezultat loše upotrebe jezika. U jednom od svojih ranijih istraživanja Spilberger (Spielberger 1966) je izneo tezu da se uticaj anksioznosti menja sa nivoom jezičkih mogućnosti, navodeći da osobama sa visokim nivoom jezičkih mogućnosti anksioznost može da bude od velike koristi, iako se jezička anksioznost vezuje prvenstveno za učenike koji su slabiji u učenju stranog jezika, a posebno je primetna kod učenika prosečnih sposobnosti. Prema tome postoji teorija da se anksioznost može posmatrati kao otežavajuća i olakšavajuća okolnost. Anksioznost kao olakšavajuća okolnost (engl. facilitating anxiety) motiviše učenike da prihvate izazove koji su pred njima, dok anksioznost kao otežavajuća okolnost (engl. debilitating anxiety) navodi učenike da izbegavaju predviđene zadatke. Makintajer (MacIntyre 1999: 27) tvrdi da jedino u slučaju kad je postavljeni zadatak relativno jednostavan, jezička anksioznost može da se shvati kao olakšavajuća okolnost. Kada je zadatak suviše komplikovan, anksioznost će automatski negativno uticati na izvođenje zadatka. Izuzevši težinu zadatka, drugi faktori kao što su stav nastavnika i ocenjivanje, međusobna interakcija nastavnika i učenika, očekivanja roditelja, stav vršnjaka iz odeljenja, mogu se takođe smatrati potencijalnim pokretačima jezičke anksioznosti. $\mathrm{Na}$ osnovu navedenog izvodi se zaključak da u polju učenja stranog jezika anksioznost tek jednim delom može da bude rezultat lošeg uspeha u savladavanju stranog jezika (Skehan 1989).

Anksioznost pri komunikaciji (engl. communication apprehension) može da se definiše kao vrsta stidljivosti koju karakteriše anksioznost pri komunikaciji sa ljudima. Takva anksioznost se oseća pri usmenoj komunikaciji sa jednom ili više osoba, uglavnom pri javnom izlaganju ili pri javnom primanju informacije. Stoga je logična pretpostavka da će osoba koja ima poteškoće u komunikaciji imati isti, ako ne i veći problem, na časovima stranog jezika (Mihaljević Djigunović 2002: 20).

Iako se uzroci anksioznosti pri komunikaciji ne mogu sa sigurnošću utvrditi, rezultati istraživanja na tu temu ističu da se ona razvija u ranom detinjstvu (Wheeles 1975). Anksioznost pri komunikaciji kod dece može da se javi kao posledica nasleđa ili kao rezultat uticaja sredine - kulture, roditelja, škole, vršnjaka itd., a dokazano je i da faktori kao što su nagrada ili kazna, usvajanje veština i oponašanje komunikativnog stila roditelja značajno utiču na razvoj anksioznosti pri komunikaciji (Richmond and McCroskey 1998: 49-50). Nijedan od navedenih faktora se, međutim, ne može izdvojiti kao ključan, već 
interakcija svih aspekata nasleđa i uticaja sredine kao rezultat ima stvaranje sklonosti i predispozicija za ovu vrstu anksioznosti kod odrasle osobe.

Prema tome, osoba koja oseća da ima predispozicije da razvije anksioznost pri komunikaciji verovatno se neće toliko često upuštati u razgovore s drugima, a samim tim neće dobiti povratnu informaciju od sagovornika, što bi je ohrabrilo da se slobodnije upušta u buduće razgovore. Prema tome, kod takve osobe se smanjuje želja za komunikacijom, što je sprečava da razvije neophodne veštine potrebne za vođenje uspešne komunikacije sa drugima, a ukoliko u okolini ne postoje adekvatni uzori čije bi ponašanje mogla da oponaša, takva osoba će se naći u još većem problemu (Mihaljević Djigunović 2002).

Sem toga, situacije u kojima se ocenjuju komunikativne sposobnosti u okviru razredne situacije mogu dodatno da izazovu osećaj anksioznosti pri komunikaciji. U razrednoj situaciji od učenika se očekuje da se usmeno izražavaju, što znači da će učenici koji se slabije snalaze u takvim situacijama, tj. učenici koji se ne izražavaju tečno, često imati i slabije ocene jer produkcija jezika, u tom slučaju neće biti adekvatan pokazatelj znanja. Takvi učenici su najčešće i svesni svog problema, što neretko dovodi do pojave anksioznosti pri komunikaciji već pri samoj pomisli na takvu situaciju. Učenicima sa takvim problemom najviše odgovara nastava frontalnog tipa, jer im prijaju situacije u kojima nisu u obavezi da aktivno učestvuju u nastavi. Deci koja osećaju anksioznost pri komunikaciji na stranom jeziku takva atmosfera upravo i prija te se veoma lako uklapaju u nju. Sem toga, ako se u obzir uzmu uslovi u kojim se u školi radi, tj. veliki broj učenika u odeljenju, nedovoljno prostora i sredstava za rad, jasno je zašto nastavnicima ponekad lakše da deca budu tiha u toku nastave. Decu koja su tiha i ne prave buku na času nastavnici često i ohrabruju da nastave s takvim ponašanjem, a decu koja su bučnija grde, što učenicima koji osećaju anksioznost pri komunikaciji služi kao podsetnik da im, ukoliko progovore, sledi kritika. Prema tome, ovakvo održavanje discipline u razrednoj situaciji dodatno doprinosi introvertnosti učenika (Richmond and McCroskey 1998: 50).

Postoji mnogo teorija o tome kako nastaje jezička anksioznost. Horvic i Jang (Horwitz and Young 1991: 1) navode da je jezičku anksioznost moguće posmatrati kao manifestaciju drugih oblika anksioznosti kao što su anksioznost pri komunikaciji, ispitna anksioznost i strah od negativne društvene evaluacije.

Makroski (McCroskey 1978: 78) definiše anksioznost pri komunikaciji kao individualni nivo anksioznosti koji je povezan sa stvarnim ili očekivanim razgovorom sa drugom osobom. Horvic, Horvic i Koup (Horwitz, Horwitz and Cope, 1986: 127) uvrštavaju ovu definiciju anksioznosti pri usmenoj komunikaciji u svoj koncept anksioznosti pri učenju stranog jezika. Oni smatraju da su interpersonalne interakcije veoma bitne za učenje stranog jezika jer ono 
podrazumeva ne samo sušto učenje već i usmenu reprodukciju jezika. Usmena komunikacija se sastoji iz dva dela: slušanja i govora. Govor na stranom jeziku je vrsta aktivnosti koja izaziva anksioznost kod većine učenika, a posebno ako takva situacija podrazumeva usmeno izražavanje pred vršnjacima u odeljenju (Young 1986).

To dovodi do zaključka da je anksioznost pri komunikaciji izuzetno važna za definisanje jezičke anksioznosti, jer u prvi plan stavlja interpersonalnu interakciju, te će se u okviru ovog rada posebna pažnja posvetiti istraživanju navedene dve vrste anksioznosti.

\section{METODOLOGIJA ISTRAŽIVANJA}

U istraživanju za ovaj rada učestvovala su 142 učenika osnovne škole „Svetozar Marković Toza“ iz Novog Sada. Svi učenici pohađali su šesti razred, a među njima se nalazilo $52,82 \%$ dečaka i $47,18 \%$ devojčica. Svi učenici su u vreme anketiranja imali između 12 i 13 godina.

Instrument korišćen u istraživanju je anketa čiji je sastavni deo upitnik skaler za merenje jezičke anksioznosti u razrednoj situaciji. Upitnik skaler predstavlja prilagođenu verziju Skale za merenje jezičke anksioznosti u razrednoj situaciji - FLCAS (engl. Foreign Language Classroom Anxiety Scale) koju su osmislili Horvic, Horvic i Koup (Horwitz, Horwitz andS Cope 1986), a koja se bazira na petostepenoj Likertovoj skali ( 5 - u potpunosti se slažem, 4 - slažem se, 3 -neutralan sam, 2 - ne slažem se, 1 - uopšte se ne slažem) i sadrži 33 stavke čiji je cilj da izmere nivo prisustva jezičke anksioznosti u razrednoj situaciji i njenih podvrsta - anksioznosti pri komunikaciji, straha od negativne društvene evaluacije i ispitne anksioznosti. Za potrebe kvantitativnog ispitivanja jezičke anksioznosti kod učenika šestog razreda, takođe je korišćen upitnik skaler, ali u ovom slučaju sa trostepenom skalom, jer je autorka na osnovu rada sa učenicima šestog razreda, a pozivajući se na iskustva autora koji su takođe koristili prilagođenu verziju ovog upitnika (Khan and Al-Mahrooqi 2015), pretpostavila da bi petostepena skala bila suviše komplikovana za njihov uzrast. Iz istog razloga su u ovom slučaju izostavljene sve negativno kodirane tvrdnje. Svakako treba napomenuti da su stavke iz ove vrste upitnika formirane po uzoru na stavke iz originalne Skale za merenje jezičke anksioznosti u razrednoj situaciji ali su uprošćene s ciljem da budu razumljive učenicima šestog razreda. Prema tome, petostepena Likertova skala zamenjena je trostepenom, a broj stavki je redukovan na 12 . 
U okviru ovog rada analiziraće se celokupna prilagođena skala za merenje jezičke anksioznosti u razrednoj situaciji kako bi se odredio nivo prisutnosti opšte anksioznosti među učenicima šestog razreda, te posebno stavke koje pripadaju kategoriji anksioznosti pri komunikaciji, a to su: 1, 2, 3, 10.

Podaci su kodirani i statistički obrađeni paketom SPPS for Windows. U okviru analize podataka prvo se tumače rezultati dobijeni upotrebom prilagođene skale za merenje jezičke anksioznosti u razrednoj situaciji, a potom uticaj eksternog faktora koji se odnosi na dodatno učenje engleskog jezika.

\section{REZULTATI}

Pri analizi podataka dobijenih pomoću prilagođene verzije upitnika za ispitivanje opšteg nivoa jezičke anksioznosti u razrednoj situaciji krenulo se od analize srednje vrednosti, pomoću koje se može utvrditi nivo jezičke anksioznosti među ispitanim učenicima. Originalna skala za merenje jezičke anksioznosti $\mathrm{u}$ razrednoj situaciji je petostepena, pri čemu su neke od tvrdnji obrnuto, tj. negativno kodirane. Ukupni raspon bodova se kreće od 33 do 165, a hipotetički prosečni raspon varijacije je 99 . Sa većim rezultatom povećava se i nivo jezičke anksioznosti. Za potrebe istraživanja u ovom radu korišćen je upitnik skaler sa trostepenom skalom pri čemu su izbačene sve negativno kodiranje tvrdnje $s$ ciljem da svaka od njih bude potpuno razumljiva učenicima šestog razreda. Kod ove skale ukupni raspon bodova kreće se od 12 do 36, a hipotetički prosečni raspon varijacije je u tom slučaju 21 .

S obzirom da je srednja vrednost rezultata prilagođenog upitnika za učenike šestog razreda u ovom slučaju 20,83, to u odnosu na hipotetički prosečni raspon varijacije od 21 govori da je kod učenika šestih razreda osnovne škole prisutan umeren nivo jezičke anksioznosti.

Tabela 1. daje detaljan pregled rezultata upitnika skalera koji su ispunili učenici šestog razreda.

\begin{tabular}{|l|r|}
\hline Mere disperzije (varijabilnosti) & Šesti razredi \\
\hline $\mathrm{N}$ & 142 \\
\hline Aritmetička sredina & 20,83 \\
\hline Medijan & 20,00 \\
\hline Mod & 24,00 \\
\hline Standardna devijacija & 4,67 \\
\hline Raspon varijacije & 21,00 \\
\hline
\end{tabular}




\begin{tabular}{|l|r|}
\hline Minimum & 12,00 \\
\hline Maksimum & 33,00 \\
\hline
\end{tabular}

Tabela 1. Rezultati upitnika skalera

S obzirom da je analizom srednje vrednosti upitnika skalera utvrđeno da kod učenika postoji umeren nivo jezičke anksioznosti, sledeći cilj je da se identifikuje postojanje anksioznosti pri komunikaciji kod ispitanih učenika. S obzirom da se prema interpretaciji autora Skale za merenje jezičke anksioznosti $\mathrm{u}$ razrednoj situaciji ispitanici sa srednjom vrednosti oko 3 smatraju umereno anksioznima, u slučaju prilagođene verzije ovog upitnika gde se umesto petostepene skale kod koje je prosečna vrednost 3 , koristila trostepena skala, prosečna vrednost je u tom slučaju 1,5, a prisutnost jezičke anksioznosti je vidljiva $\mathrm{u}$ sledećem rasponu: 1-1,25 niska jezička anksioznost, 1,25-1,75 umereno prisutna jezička anksioznost, i 1,75-3 izražena jezička anksioznost (v. Prilog 2).

Za potrebe ovog rada, autorka je interpretirala podatke dobijene analizom tvrdnji koje se svrstavaju u kategoriju anksioznosti pri komunikaciji, te je pregledom srednjih vrednosti i standardne devijacije utvrdila u kojoj meri je anksioznost pri komunikaciji prisutna kod anketiranih učenika (v. Tabelu 2).

\begin{tabular}{|l|c|c|c|}
\hline $\begin{array}{l}\text { Prilagođena verzija Skale za merenje jezičke anksioznosti za } \\
\text { učenike 6. razreda (raspon skale 1-3) }\end{array}$ & N & AS & SD \\
\hline *1. Broj časova engleskog jezika u školi je sasvim dovoljan. & 142 & 1,54 & 0,85 \\
\hline $\begin{array}{l}\text { **2. Mislim da bi učenici bolje znali engleski jezik da imaju više } \\
\text { časova engleskog jezika u školi. }\end{array}$ & 142 & 1,80 & 0,92 \\
\hline *3. Imam tremu kada treba da pričam engleski na času. & 142 & 1,58 & 0,83 \\
\hline *10. Strah me je da se javim na času engleskog jezika. & 142 & 1,70 & 0,90 \\
\hline Anksioznost pri komunikaciji & 142 & 1,65 & 0,87 \\
\hline
\end{tabular}

Tabela 2. Anksioznosti pri komunikaciji

$\mathrm{S}$ obzirom da vrednosti koje se nalaze u rasponu 1,25-1,75 ukazuju na umereno prisustvo anksioznosti, kod učenika šestog razreda aritmetička sredina u kategoriji anksioznosti pri komunikaciji iznosi 1,65 (AS=1,65) što znači da je kod njih ova vrsta anksioznosti umereno prisutna. Ako se detaljnije pogledaju odgovori učenika na postavljene tvrdnje iz kategorije anksioznosti pri komunikaciji može se uočiti da se tvrdnja pod rednim brojem 2 ,Mislim da bi 
učenici bolje znali engleski jezik da imaju više časova engleskog jezika u školi,“ $(\mathrm{AS}=1,80)$ ističe $\mathrm{u}$ odnosu na ostale tvrdnje iz upitnika. Kod ostalih tvrdnji anksioznost je umereno prisutna.

S obzirom da se deskriptivnom statističkom analizom rezultata upitnika skalera utvrdilo da je anksioznost posebno izražena kod druge tvrdnje koja se odnosi na broj časova koje učenici imaju u školi, urađena je dodatna statistička analiza upravo ovog eksternog faktora kako bi se utvrdio njegov uticaj kako na pojavu jezičke anksioznosti u razrednoj situaciji uopšte, tako i na pojavu anksioznosti pri komunikaciji.

\subsection{Pohađanje privatnih časova engleskog jezika}

Pohađanje privatnih časova engleskog jezika je sve prisutnije, ne samo među studentima i srednjoškolcima već i među učenicima osnovne škole. S obzirom da su učenici osnovne škole u okviru razredne nastavne časovima engleskog jezika izloženi tek dva puta nedeljno u trajanju od po 45 minuta, mnogi roditelji se trude da, ukoliko su u mogućnosti, deci obezbede dodatnu nastavu engleskog jezika van škole. U okviru istraživanja, od ukupno 142 učenika većina učenika $(60,56 \%)$ ne pohađa privatne časove, što znači da je većina učenika učenju engleskog jezika izložena jedino u okviru redovne nastave u školi. Tabela 3. daje pregled podataka u vezi sa pohađanjem privatnih časova, načinom i učestalošću učenja engleskog jezika van škole.

\begin{tabular}{|l|l|c|c|}
\hline \multicolumn{2}{|c|}{ Učenje engleskog jezika van škole } & \multicolumn{2}{c|}{ Šesti razredi } \\
\cline { 3 - 4 } & Frekvencija & $\%$ \\
\hline $\begin{array}{l}\text { Da li učiš engleski van } \\
\text { škole? }\end{array}$ & $\mathrm{Da}$ & 56 & 39,43 \\
\cline { 2 - 4 } & $\mathrm{Ne}$ & 86 & 60,56 \\
\hline $\begin{array}{l}\text { Način učenja engleskog } \\
\text { van škole }\end{array}$ & Privatni časovi & 28 & 50 \\
\cline { 2 - 4 } & Privatna škola & 28 & 50 \\
\hline $\begin{array}{l}\text { Učestalost učenja } \\
\text { engleskog jezika van škole } l\end{array}$ & $\begin{array}{l}\text { Samo pred } \\
\text { kontrolni }\end{array}$ & 16 & 28,57 \\
\cline { 2 - 4 } & Jednom nedeljno & 8 & 14,28 \\
\cline { 2 - 4 } & Dva puta nedeljno & 38 & 67,85 \\
\hline
\end{tabular}

Tabela 3. Učenje engleskog jezika van škole

1 Ukupan procentualni zbir učenika kod ovog pitanja iznosi 110,7 iz razloga što su neki od učenika koji inače ne uče engleski jezik privatno zaokružili jedan od ponuđenih odgovora jer u određenim periodima ipak imaju pomoć pri učenju engleskog jezika (od strane članova porodice ili prijatelja). 
Upotrebom $t$-testa uočava se da kod generacije učenika šestog razreda postoji statistički značajna razlika između dodatnog učenja engleskog jezika van redovne nastave i nivoa opšte anksioznosti i anksioznosti pri komunikaciji (v. Tabelu 4).

\begin{tabular}{|c|c|c|c|c|c|c|c|}
\hline $\begin{array}{c}\text { Da li učiš engleski } \\
\text { jezik van škole? }\end{array}$ & Odgovor & $\mathrm{N}$ & AS & $\mathrm{SD}$ & $\begin{array}{l}\text { Razlika } \\
\text { AS }\end{array}$ & $t$ & $p$ \\
\hline \multirow{2}{*}{$\begin{array}{l}\text { Anksioznost pri } \\
\text { komunikaciji }\end{array}$} & DA & 56 & 1,61 & 0,42 & \multirow{2}{*}{$-0,44$} & \multirow{2}{*}{$-5,799$} & \multirow{2}{*}{0,000} \\
\hline & $\mathrm{NE}$ & 86 & 2,05 & 0,48 & & & \\
\hline \multirow{2}{*}{$\begin{array}{l}\text { Jezička anksioznost } \\
\text { Anksioznost pri } \\
\text { komunikaciji }\end{array}$} & $\mathrm{DA}$ & 56 & 1,61 & 0,34 & \multirow[b]{2}{*}{$-0,29$} & \multirow[b]{2}{*}{$-4,598$} & \multirow[b]{2}{*}{0,000} \\
\hline & $\mathrm{NE}$ & 86 & 1,90 & 0,38 & & & \\
\hline
\end{tabular}

Tabela 4. Dodatno učenje engleskog jezika

S obzirom da je značajnost uočljiva na nivou $p<0,000$ i da je aritmetička sredina viša za učenike koji ne uče engleski jezik van škole, može da se zaključi da je anksioznost pri komunikaciji visoko izražena kod učenika koji engleski jezik uče isključivo u razrednoj situaciji u okvirima redovne nastave $(\mathrm{AS}=2,05)$ nego što je to slučaj kod učenika koji engleski jezik uče dodatno $(A S=1,61)$.

Učenici koji dodatno uče engleski jezik van razredne nastave uglavnom pohađaju privatne časove engleskog jezika ili idu na časove engleskog jezika u privatne škole. Procentualnim pregledom odgovora učenika ispostavlja se da jednak broj učenika pohađa jedan od ova dva oblika dodatne nastave (v. Tabelu 5). S obzirom da se časovi u privatnim školama engleskog jezika odvijaju u proseku dva puta nedeljno za razliku od privatnih časova engleskog jezika koje učenici neretko pohađaju tek po potrebi i pred pismeni ili kontrolni zadatak, nadalje je urađena analiza upotrebom $t$-testa s ciljem da pokaže da li postoji statistički značajna razlika u nivou ispitne anksioznosti između učenika koji privatno engleski jezik uče redovno i onih koji to tek povremeno čine (v. Tabelu $5)$. 


\begin{tabular}{|c|c|c|c|c|c|c|c|}
\hline Vrsta dodatne nastave & Odgovor & $\mathrm{N}$ & $\mathrm{AS}$ & SD & $\begin{array}{c}\text { Razlika } \\
\text { AS }\end{array}$ & $t$ & $p$ \\
\hline \multirow{2}{*}{$\begin{array}{l}\text { Anksioznost pri } \\
\text { komunikaciji }\end{array}$} & Škola & 28 & 1,64 & 0,40 & \multirow{2}{*}{$-0,25$} & \multirow{2}{*}{$-3,176$} & \multirow{2}{*}{0,002} \\
\hline & Časovi & 28 & 1,89 & 0,53 & & & \\
\hline \multirow{2}{*}{$\begin{array}{l}\text { Jezička anksioznost } \\
\text { Anksioznost pri } \\
\text { komunikaciji }\end{array}$} & Škola & 28 & 1,60 & 0,30 & \multirow[b]{2}{*}{$-0,24$} & \multirow[b]{2}{*}{$-3,909$} & \multirow[b]{2}{*}{0,000} \\
\hline & Časovi & 28 & 1,85 & 0,42 & & & \\
\hline
\end{tabular}

Tabela 5. Vrsta dodatne nastave

Iz gore predstavljenih podataka se vidi da kod ispitanih učenika koji pohađaju neki vid dodatne nastave engleskog jezika postoji statistički značajna razlika u izraženosti opšte anksioznosti i anksioznosti pri komunikaciji. Nivo opšte anksioznosti i anksioznosti pri komunikaciji je viši kod učenika koji pohađaju privatne časove nego kod učenika koji idu u privatne škole engleskog jezika. S obzirom da su se učenici izjasnili da časove pohađaju jednom nedeljno, dva puta nedeljno ili tek pred kontrolni i pismeni zadataka urađena je dodatna statistička analiza podataka upotrebom ANOVA testa, nakon čega je upotrebom post-hoc Bonferoni testa dobijen podatak da učenici koji su češće izloženi uticaju stranog jezika ujedno imaju i niži nivo opšte anksioznosti ali i anksioznosti pri komunikaciji.

\section{DISKUSIJA}

Kako je osnovni cilj ovog rada da ustanovi nivo jezičke anksioznosti i anksioznosti pri komunikaciji među učenicima šestog razreda osnovne, u istraživanje se krenulo na osnovu tri prethodno formulisana istraživačka zadatka. Prema tome, na osnovu prvog istraživačkog zadatka trebalo je utvrditi da li je jezička anksioznost prisutna kod učenika šestog razreda osnovne škole. Na osnovu srednjih vrednosti korišćenog upitnika skalera (koji po svojoj strukturi predstavlja prilagođenu verziju Skale za merenje jezičke anksioznosti u razrednoj situaciji) izveden je zaključak da je jezička anksioznost umereno prisutna kod ispitanih učenika. Ovi rezultati odgovaraju rezultatima drugih autora (PérezParedes and Martínez-Sánchez 2000; Horwitz et al. 1986; Aida 1994) jer dobijeni podaci ukazuju na manja odstupanja u nivou jezičke anksioznosti među 
učenicima, što dodatno potvrđuje validnost upotrebe prilagođene verzije Skale za merenje jezičke anksioznosti u razrednoj situaciji.

$\mathrm{S}$ obzirom da se problem jezičke anksioznosti može sagledati kroz tri međusobno povezane vrste anksioznosti (anksioznost pri komunikaciji, ispitna anksioznosti i strah od negativne društvene evaluacije, u okviru drugog istraživačkog zadataka trebalo je da se utvrdi da li je anksioznost pri komunikaciji prisutna kod učenika šestog razreda osnovne škole. Analizom srednjih vrednosti tvrdnji koje spadaju u kategoriju anksioznosti pri komunikaciji utvrđeno je da srednja vrednost iznosi 1,65 (AS=1,65), što upućuje na umereno prisustvo anksioznosti pri komunikaciji u okviru razredne situacije. Pojedinačnom analizom stavki kod kojih je anksioznost pri komunikaciji najprimetnija, zaključuje se da je ona najizraženija kod učenika koji smatraju da bi engleski jezik bolje savladali kada bi imali više časova engleskog jezika u školi.

U okviru trećeg istraživačkog zadatka trebalo je utvrditi da li eksterni faktor koji se odnosi na pohađanje privatnih časova engleskog jezika utiče na pojavu jezičke anksioznosti u razrednoj situaciji i anksioznosti pri komunikaciji. Statistička analiza upotrebom $t$-testa je pokazala postojanost statistički značajne razlike između dodatne izloženosti uticaju stranog jezika u vidu pohađanja privatnih časova i škola i opšte jezičke anksioznosti, kao i anksioznosti pri komunikaciji. S obzirom da su učenici izjavili da dodatno uče engleski u okviru privatnih škola i privatnih časova, daljom statističkom analizom se potvrdilo da su učenici koji pohađaju privatne škole manje anksiozni i po pitanju opšte anksioznosti i u okviru anksioznosti pri komunikaciji od učenika koji idu na privatne časove. Ovi podaci navode na zaključak da učenici koji pohađaju privatne škole engleski jezik uče redovno dva puta nedeljno, dok učenici koji pohađaju privatne časove to čine uglavnom pred usmene i pismene provere znanja. Iz prakse je poznato da na privatne časove uglavnom idu učenici sa slabijim znanjem da bi pred pismeni ili kontrolni zadatak ponovili ili naučili gradivo. Dalja analiza upotrebom post-hoc testa je to i potvrdila pokazavši da učenici koji engleski jezik pohađaju češće ujedno imaju i niži nivo opšte anksioznosti i anksioznosti pri komunikaciji zbog češće izloženosti stranom jeziku.

\section{ZAKLJUČAK}

Većina istraživanja koja se baziraju na proučavanju jezičke anksioznosti uglavnom se bavi kvantitativnom analizom podataka dobijenih upotrebom originalne ili prilagođene verzije Skale za merenje jezičke anksioznosti u 
razrednoj situaciji (Horwitz et al. 1986). Prema tome, i ovaj rad imao je za cilj da dâ statistički pregled rezultata dobijenih upotrebom modifikovane verzije ove skale u okviru opšte anksioznosti u razrednoj situaciji i jedne od njenih osnovnih komponenti - anksioznosti pri komunikaciji. U istraživanju su učestvovali učenici šestog razreda, a rezultati su ukazali na umereno prisustvo kako opšte tako i anksioznosti pri komunikaciji. S obzirom da se pri deskriptivnoj statističkoj analizi tvrdnji iz prilagođene skale moglo zaključiti da je jezička anksioznost najizraženija kod tvrdnje koja se odnosi na mali broj časova engleskog jezika u okviru razredne situacije, izvršena je dalja analiza eksternog faktora koji se odnosi na dodatno pohađanje nastave engleskog jezika. Na ovaj način su dobijeni značajni podaci koji otkrivaju da bi potencijalni uzrok pojavljivanja opšte anksioznosti ali i anksioznosti pri komunikaciji mogao biti upravo mali broj časova engleskog jezika u okviru redovne nastave. Rezultati su takođe pokazali da dodatna izloženost uticaju engleskog jezika uistinu utiče na smanjenje nivoa jezičke anksioznosti, posebno ako se dodatni časovi odvijaju redovno. Prema tome autorka ističe značaj sprovođenja ovakvih istraživanja kako bi se otkrili pravi uzroci pojave jezičke anksioznosti u razrednoj situaciji te kako bi se pojava anksioznosti pri komunikaciji, koja je neizostavan faktor u oblasti učenja stranog jezika, svela na minimum. U nadi da će se ovakva i slična istraživanja nastaviti u našoj zemlji, autorka upućuje na neophodnost detaljnijeg istraživanja ove oblasti primenjene lingvistike i u okviru ostalih kategorija koje utiču na pojavu jezičke anksioznosti kako bi se dobila sveobuhvatna slika ovog problema.

\section{LITERATURA}

Aida, Y. (1994). "Examination of Horwitz, Horwitz and Cope's construct of foreign language anxiety: The case of students of Japanese“. The Modern Language Journal 78 (2): 155-168.

Foss, A. K. (1991). "A Relational Model for Managing Second Language Anxiety", In Language Anxiety: From Theory and Research to Classroom Implications, ed. E. H. Young (Englewood Cliffs, NJ: Prentice Hall).

Goshi, M. (2005). "Foreign Language Classroom Anxiety: How Should The Classroom Teacher Deal With?“". Journal of The School of Marine Science and Technology 3 (2): 61-65.

Horwitz, E. K., Horwitz, M. B. and J. Cope (1986). "Foreign language classroom anxiety". The Modern Language Journal 70: 125-132.

Horwitz, E. K. and D. J. Young (1991). Language Anxiety. From Theory and Research to Classroom Implications. New Jersey: Prentice Hall. 
Khan, A. and R. Al-Mahrooqi (2015). "Foreign Language Communication Anxiety (FLCA) among Tertiary Level Omani EFL Learners". The Asian EFL Journal 17 (1): 57-85.

McCroskey, J. C. (1978). "Validity of the PRCA as an index of oral communication apprehension". Communication Monographs 45: 192-203.

Mihaljević Djigunović, J. (2002). Strah od stranog jezika. Zagreb: Naklada Ljevak.

Pérez-Paredes, P. and F. Martínez-Sánchez (2000-2001). "A Spanish version of the foreign language classroom anxiety scale: Revisiting Aida's factor analysis“. Revista Española de Lingüistica Aplicada RESLA 14: 337-352.

Richmond, V. and J. McCroskey (1998). Communication apprehension, avoidance, and effectiveness. MA: Allyn and Bacon.

Rodriguez, M. and O. Abreu (2003). "The stability of general foreign language classroom anxiety across English and French". The Modern Language Journal 87 (3): 356-374.

Skehan, P. (1989). Individual differences in second language learning. London: Edward Arnold.

Spielberger, C. D. (1966). "Theory and research on anxiety", In Anxiety and behaviour, ed. C. D. Spielberger (New York: Academic Press): 3-20.

Wheeless, L. R. (1975). "An Investigation of receiver apprehension and social context dimensions of communication apprehension". Journal of Experimental Child Psychology 22: 302-308.

Young, D. (1986). "The relationship between anxiety and foreign language oral proficiency ratings", In Language anxiety: From theory and research to classroom implications, ed. E. K. Young (Englewood Cliffs, NJ: PrenticeHall): 57-63. 
Radmila R. Suzić

University Singidunum

Belgrade

radmila.suzic@gmail.com

\section{FOREIGN LANGUAGEE ANXIETY AND COMMUNICATION APPREHENSION IN A CLASSROOM SITUATION}

\section{Summary}

Foreign language anxiety is a factor that can be found in any form of learning a foreign language. One of the main components of foreign language anxiety in a classroom situation is communication apprehension, a problem faced by everyone who needs to verbally produce a foreign language. Therefore, this paper analyzes the problems of foreign language anxiety and communication apprehension of the sixth grade students of elementary school. Data are collected by questionnaire, a customized version of FLCAS - Foreign Language Classroom Anxiety Scale, statistically analyzed in order to determine the levels of foreign language anxiety and communication apprehension among aforementioned students. In addition, the influence of attending additional classes of the English language was also analyzed, in order to determine if a more frequent exposure to foreign language influences the level of both types of language anxiety. The results showed that an insufficient exposure to the English language within a classroom, in the context of regular classes, is one of the causes of the foreign language anxiety and communication apprehension among sixth grade students of elementary school.

Key words: foreign language anxiety, communication apprehension, English, primary school.

Prilog 1

Skala za merenje jezičke anksioznosti u razrednoj situaciji (Horwitz, Horwitz and Cope, 1986)

$\begin{array}{lll}1 & - & \text { strongly agree } \\ 2 & - & \text { agree } \\ 3 & - & \text { neither agree nor disagree } \\ 4 & - & \text { disagree } \\ 5 & - & \text { strongly disagree }\end{array}$

\begin{tabular}{|l|l|l|l|l|l|}
\hline $\begin{array}{l}\text { 1. I never feel quite sure of myself when I am speaking in my foreign } \\
\text { language class. }\end{array}$ & 1 & 2 & 3 & 4 & 5 \\
\hline 2. I don't worry about making mistakes in language class. & 1 & 2 & 3 & 4 & 5 \\
\hline
\end{tabular}




\begin{tabular}{|c|c|c|c|c|c|}
\hline $\begin{array}{l}\text { 3. I tremble when I know that I'm going to be called on in language } \\
\text { class. }\end{array}$ & 1 & 2 & 3 & 4 & 5 \\
\hline $\begin{array}{l}\text { 4. It frightens me when I don't understand what the teacher is saying in } \\
\text { the foreign language. }\end{array}$ & 1 & 2 & 3 & 4 & 5 \\
\hline 5. It wouldn't bother me at all to take more foreign language classes. & 1 & 2 & 3 & 4 & 5 \\
\hline $\begin{array}{l}\text { 6. During language class, I find myself thinking about things that have } \\
\text { nothing to do with the course. }\end{array}$ & 1 & 2 & 3 & 4 & 5 \\
\hline $\begin{array}{l}\text { 7. I keep thinking that the other students are better at languages than I } \\
\text { am. }\end{array}$ & 1 & 2 & 3 & 4 & 5 \\
\hline 8. I am usually at ease during tests in my language class. & 1 & 2 & 3 & 4 & 5 \\
\hline $\begin{array}{l}\text { 9. I start to panic when I have to speak without preparation in language } \\
\text { class. }\end{array}$ & 1 & 2 & 3 & 4 & 5 \\
\hline $\begin{array}{l}\text { 10. I worry about the consequences of failing my foreign language } \\
\text { class. }\end{array}$ & 1 & 2 & 3 & 4 & 5 \\
\hline $\begin{array}{l}\text { 11. I don't understand why some people get so upset over foreign } \\
\text { language classes. }\end{array}$ & 1 & 2 & 3 & 4 & 5 \\
\hline 12. In language class, I can get so nervous I forget things I know. & 1 & 2 & 3 & 4 & 5 \\
\hline 13. It embarrasses me to volunteer answers in my language class. & 1 & 2 & 3 & 4 & 5 \\
\hline $\begin{array}{l}\text { 14. I would not be nervous speaking the foreign language with native } \\
\text { speakers. }\end{array}$ & 1 & 2 & 3 & 4 & 5 \\
\hline 15. I get upset when I don't understand what the teacher is correcting. & 1 & 2 & 3 & 4 & 5 \\
\hline $\begin{array}{l}\text { 16. Even if I am well prepared for language class, I feel anxious about } \\
\text { it. }\end{array}$ & 1 & 2 & 3 & 4 & 5 \\
\hline 17. I often feel like not going to my language class. & 1 & 2 & 3 & 4 & 5 \\
\hline 18. I feel confident when I speak in foreign language class. & 1 & 2 & 3 & 4 & 5 \\
\hline $\begin{array}{l}\text { 19. I am afraid that my language teacher is ready to correct every } \\
\text { mistake I make. }\end{array}$ & 1 & 2 & 3 & 4 & 5 \\
\hline $\begin{array}{l}\text { 20. I can feel my heart pounding when I'm going to be called on in } \\
\text { language class. }\end{array}$ & 1 & 2 & 3 & 4 & 5 \\
\hline 21. The more I study for a language test, the more confused I get. & 1 & 2 & 3 & 4 & 5 \\
\hline 22. I don't feel pressure to prepare very well for language class. & 1 & 2 & 3 & 4 & 5 \\
\hline $\begin{array}{l}\text { 23. I always feel that the other students speak the foreign language } \\
\text { better than I do. }\end{array}$ & 1 & 2 & 3 & 4 & 5 \\
\hline $\begin{array}{l}\text { 24. I feel very self-conscious about speaking the foreign language in } \\
\text { front of the other students. }\end{array}$ & 1 & 2 & 3 & 4 & 5 \\
\hline 25. Language class moves so quickly I worry about getting left behind. & 1 & 2 & 3 & 4 & 5 \\
\hline $\begin{array}{l}\text { 26. I feel more tense and nervous in my language class than in my } \\
\text { other classes. }\end{array}$ & 1 & 2 & 3 & 4 & 5 \\
\hline
\end{tabular}




\begin{tabular}{|c|c|c|c|c|c|}
\hline $\begin{array}{l}\text { 27. I get nervous and confused when I am speaking in my language } \\
\text { class. }\end{array}$ & 1 & 2 & 3 & 4 & 5 \\
\hline $\begin{array}{l}28 . \text { When I'm on my way to language class, I feel very sure and } \\
\text { relaxed. }\end{array}$ & 1 & 2 & 3 & 4 & 5 \\
\hline $\begin{array}{l}\text { 29. I get nervous when I don't understand every word the language } \\
\text { teacher says. }\end{array}$ & 1 & 2 & 3 & 4 & 5 \\
\hline $\begin{array}{l}\text { 30. I feel overwhelmed by the number of rules you have to learn to } \\
\text { speak a foreign language. }\end{array}$ & 1 & 2 & 3 & 4 & 5 \\
\hline $\begin{array}{l}\text { 31. I am afraid that the other students will laugh at me when I speak } \\
\text { the foreign language. }\end{array}$ & 1 & 2 & 3 & 4 & 5 \\
\hline $\begin{array}{l}\text { 32. I would probably feel comfortable around native speakers of the } \\
\text { foreign language. }\end{array}$ & 1 & 2 & 3 & 4 & 5 \\
\hline $\begin{array}{l}\text { 33. I get nervous when the language teacher asks questions which I } \\
\text { haven't prepared in. }\end{array}$ & 1 & 2 & 3 & 4 & 5 \\
\hline
\end{tabular}

Prilog 2

Prilagođena verzija upitnika FLCAS za učenike šestog razreda

1 - Slažem se

2 - Nemam mišljenje

3 - Ne slažem se

\begin{tabular}{|l|c|c|c|}
\hline 1. Broj časova engleskog jezika u školi je sasvim dovoljan. & 1 & 2 & 3 \\
\hline $\begin{array}{l}\text { 2. Mislim da bi učenici bolje znali engleski jezik da imaju više časova engleskog } \\
\text { jezika u školi. }\end{array}$ & 1 & 2 & 3 \\
\hline 3. Imam tremu kada treba da pričam engleski na času. & 1 & 2 & 3 \\
\hline 4. Neugodno mi je kada me nastavnik prozove da pričam na engleskom jeziku. & 1 & 2 & 3 \\
\hline $\begin{array}{l}\text { 5. Ponekad se na času engleskog jezika toliko uplašim da zaboravim i ono što sam } \\
\text { znao/la. }\end{array}$ & 1 & 2 & 3 \\
\hline 6. Neugodno mi je kada me nastavnik ispravlja kada pogrešim. & 1 & 2 & 3 \\
\hline $\begin{array}{l}\text { 7. Stid me je da priznam ako ne razumem šta nastavnik objašnjava na engleskom } \\
\text { jeziku. }\end{array}$ & 1 & 2 & 3 \\
\hline 8. Moji drugari bolje govore engleski od mene. & 1 & 2 & 3 \\
\hline 9. Moji drugari mi se često smeju kada pogrešim dok govorim na engleskom jeziku. & 1 & 2 & 3 \\
\hline 10. Strah me je da se javim na času engleskog jezika. & 1 & 2 & 3 \\
\hline 11. Imam tremu pred odgovaranje iz engleskog jezika. & 1 & 2 & 3 \\
\hline 12. Imam veću tremu kada treba da odgovaram engleski nego neki drugi predmet. & 1 & 2 & 3 \\
\hline
\end{tabular}

Primljeno: 29. 3. 2016.

Prihvaćeno: 5. 5. 2016. 